International Journal of Business Management and Economic Review

Vol. 4, No. 04; 2021

ISSN: 2581-4664

\title{
THE EFFECT OF E-WOM ON PURCHASE INTENTION THROUGH ATTITUDE WITH SOVC AS A MODERATING VARIABLE ON THE FOLLOWERS OF INSTAGRAM ACCOUNT "KOMUNITAS PECANDU BUKU”
}

\author{
Miftahul Rizmi, Permana Honneyta Lubis and Syafruddin Chan \\ Management Department,Universitas Syiah Kuala, Indonesia \\ http://doi.org/10.35409/IJBMER.2021.3305
}

\begin{abstract}
This study aims to examine the influence of eWOM towards attitude-mediated purchase intention and the power of SOVC in strengthening the effect of eWOM on both attitudes and purchase intentions. The subject was the "Komunitas Pecandu Buku" (KPB) Instagram account. Data was collected by distributing questionnaires. The sampling technique used was the purposive sampling technique, provided 260 respondents who are followers of the KBP Instagram account. This study used Structural Equation Modeling (SEM) testing. Academically, this study proves that the model consisting of the mediating effect of attitude on the influence of eWOM to purchase intention and the moderating effect of SOVC on the influence of eWOM on attitudes and the influence of attitude on the purchase intention of followers can be used to increase purchase intention. The attitude acts as a partial mediation, and the eWOM is proven to be the most dominant in influencing the purchase intention. These findings can be an academic reference and for the following research can develop this tested model by expandingto more diverse research subjects such as Facebook, Pinterest, and other social media, and alsocan add the other variables such as brand image and customer experience. Practically, this model can be implemented in organizations, especially the subject of this research, namely the KBP Instagram account.
\end{abstract}

Keyword: eWOM, SOVC, attitude, and purchase intention.

\section{INTRODUCTION}

Social media is a developing trend in society as well as a trend in marketing communications. According to (Kaplan \& Haenlein, 2010), social media is a set of applications that function on the internet network and is built based on ideology and technology that allow users to exchange information. Examples of social media widely utilized by society as a communication trend are Facebook, Twitter, Instagram.

An Instagram accounts named Komunitas Pecandu Buku (KPB) acts as a medium to promote books. In other words, it is an online book market. As of June 2019, Instagram followers of this account have reached 154,000, where followers are increasing every day with 412 official members spread throughout Indonesia. The level of monthly book sales in the five online stores figured in the KPB Instagram account is only 1,531 books. Calculated on a monthly average, it happened because the potential number of followers who transact or buy books is only $1 \%$ per 


\section{International Journal of Business Management and Economic Review}

Vol. 4, No. 04; 2021

ISSN: 2581-4664

month.This fact allows us to conclude that the interest in buying books by KPB followers is under expectation.

The low interest in buying books is inseparable from the attitude of KPB followers towards the results of the book reviews in this Instagram account. The cause of the poor attitude of followers of the KPB Instagram account to buy them is related to the message conveyed by the reviewers. The sentences that occur are the simultaneous two-way communication between the source and recipients of the information called WOM (Word of Mouth). WOM plays a crucial role in the consumer purchasing decision and shaping consumer behavior patterns (Jalilvand \& Samiei, 2012).

The rapid advancement of technology makes WOM not only a person-to-person communication towards a product or service, but also it is competent of being a variety of communications that propagate worldwide through online media. It is often called eWOM/Electronic World of Mouth (Jalilvand \& Samiei, 2012). Frequently, consumers may lack information about a product after consulting with offline friends. They can access online communities to search the relevant information to reduce uncertainty and avoid discrepancies between expected and actual product performance (Bone, 1995). Thus, the communication form of eWOM is considered the most influential towards attitudes and purchase intentions when consumers encounter unfamiliar products (Solomon \& Rabolt, 2004) and (Cheung, Luo, Sia, \& Chen, 2009).

In addition to eWOM, there is also an online community that tights a bond and similar experience in conducting searches or being a source of information. This community effect also has the best influence on changing attitudes towards a product, as is the case with online communities. Attribution theory states that the source credibility determines the persuasiveness of the message (Buda, 2003). eWOM communication is more reliable and trustworthy than the information gathered from formal marketing channels. To strengthen the influence of eWOM on attitudes, (Bansal \& Voyer, 2000) recommend adding aspects of community bonds or Sense of Community (SOC), which later became SOVC (Sense of Virtual Community).

Although there have been previous studies investigating the importance of SOVC in the context of eWOM on attitudes and purchase intentions of virtual community members (Huang, Hsiao, \& Chen, 2012), and Zhang, et.al, 2018), no one has tried to create a structure that discusses the role SOVC moderation. In addition, there is a lack of studies that attempt to visualize the relationship between eWOM and purchase intention through the attitudes of virtual community members moderated by SOVC (Huang et al., 2012). Therefore, this study aims to provide a comprehensive model to describe the moderating role of SOVC on the effect of eWOM on attitudes and the influence of attitudes on purchasing intention of virtual KPB members.

\section{LITERATURE REVIEW}

\section{eWOM (electronic Word of Mouth)}

Hennig-Thurau, et. al, (2003) defined eWOM as "a positive or negative statement made by potential and actual customers about a product or company that is available to many people or institutions through the internet media". eWOM is very popular. Thus, if eWOM is applied moderately, it has great potential to transform the market of a product from a small market to a larger market (Park \& Kim, 2008).

One type of eWOM that has an important role today is Online Review (OR) which has the power to provide essential and reliable information (Sotiriadis \& Zyl, 2013). The presence of Online 


\section{International Journal of Business Management and Economic Review}

Vol. 4, No. 04; 2021

ISSN: 2581-4664

Review (OR) provides a breakthrough in the world of marketing. It is related to the benefits of online reviews for consumers, such as taking advantage of blogging, search engines (browsers), virtual communication, social media, instant messengers, and customer reviews to collect and disseminate product information.

\section{Sense of Virtual Community (SOVC)}

Online communities consist of social objects that perform social functions with members, just as if they were in offline communities (Brown, Broderick, \& Lee, 2007) the advent of the internet and the popularity of virtual communities, people are spending more of their time interacting with online groups. As a result, people develop a sense of belonging and cohesion to online communities, establish behavioral norms, identify and trust problem-solving abilities within the community and develop emotional attachments with other community members.

A sense of virtual community (SOVC) is a feeling of belonging and attachment to a virtual community (Blanchard \& Markus, 2004). Several studies have identified this type of awareness in virtual environments (Blanchard \& Markus, 2004); (Koh \& Kim, 2003);(Roberts, Smith, \& Pollock, 2006).

\section{Attitude}

Attitude is a learned tendency to behave favorably or unfavorably towards a particular object. (Ajzen \& Fishbein, 1980) stated that attitudes are held by concerning some aspect of an individual's world, such as other people, physical entities, behavior, or policies. Therefore, the way a person reacts to his environment is called his attitude.

According to (Schiffman \& Kanuk, 2010), attitudes are a learned tendency. It means that any attitudes related to buying behavior have formed from direct experience with the product, verbal information obtained from others, or exposure to advertisements in the mass media, the internet, and various forms of direct marketing. It is important to remember that although attitudes may result from behavior, they are not the behavior itself.

\section{Purchase Intention}

Purchase intention is an antecedent (preceding factor) that stimulates and encourages the purchase of products and services. (Rahman, Haque, Elahi, \& Miah, 2015). (Ajzen, 1991) stated that purchase intention is a factor that motivates consumers and influences their behavior to make a purchase.

Referring to the theory of TPB (Ajzen \& Fishbein, 2005), there are three determinants or dimensions that determine a person's intentions, namely:

a. Attitude, a person's evaluation of an object comes from the person's beliefs about the object.

b. Subjective norms, a function of the belief that particular individuals from the group agree or refuse to perform a behavior, or that social references themselves are involved or not involved in it.

c. Behavioral control, a mindset about whether or not are the factors exist to facilitate or prevent individuals from performing a behavior.

In general, if a person has a positive attitude towards an object, gets environmental support to take definite action, and feels that there are no barriers to carrying it out, then his intention will be formidable. Thus, the possibility of the person behaving is immensely high. 
International Journal of Business Management and Economic Review

Vol. 4, No. 04; 2021

ISSN: 2581-4664

\section{Research Hypothesis}

Currently, consumers tend to look for information related to purchases (Wang \& Wang, 2010). Furthermore, (Doh \& Hwang, 2009) revealed in their research that information in eWOM form has a crucial influence on consumers' purchase intentions because they rely on eWOM before purchasing a product.

H1: It is assumed that eWOM can affect attitude.

(Fu, Ju, \& Hsu, 2015) and (Yan, Shah, Zhai, \& Khan, 2018) in their research prove that the effect of eWOM on attitudes refers to all influences, both favorable or unfavorable, on eWOM information and shows that mobile eWOM in the form of a stimulus significantly affects the emotional, affective, and cognitive responses (attitudes) of consumers.

H2: It is assumed that eWOM can affect purchase intention.

According to (Kim \& Hunter, 1993), attitude is closely related to purchase intention. Furthermore, Kim and Hunter conducted a meta-analysis study to confirm the relationship between attitudes, intentions, and behavior. According to the TRA theory and its revised TPB, (Ajzen, 1991), explains that attitudes significantly affect behavioral intentions. Intentions also link attitudes and actual behavior. Several research results support this theory, including those conducted by (Zahri \& Hafasnuddin, 2016); (Jasman \& Lubis, 2017).

H3: It is assumed that attitude can affect purchase intention.

According to (Huang et al., 2012), the product comments written in online communities are considered the matching points that influence purchase decision attitudes. (J. Q. Zhang, Craciun, \& Shin, 2010) also mention in their research that when there is an exchange of information through electronic word of mouth (eWOM), consumers will assess a product. In addition, positive eWOM can also affect potential customers and influence the purchase intention of these customers towards products recommended by other customers.

H4: It is assumed that eWOM can affect purchase intention through attitudes

According to the diagnostic-accessibility model, message diagnostics increase the likelihood of a being adopted piece of information to make a decision. When messages about judgments or choices occur as diagnostic, consumers will place greater weight on these messages when shaping their attitudes, intentions, and behaviors (Feldman \& Lynch, 1988); and (Herr, Kardes, \& Kim, 1991). Consumers view the quality of relationships and interactions as good with their online community, so they judge information from online communities to be trustworthy. It means the sense of belonging to the online community (SOVC) enhances message diagnostics, thereby intensifying the influence of eWOM on attitudes.

H5: It is assumed that SOVC can moderate the effect of eWOM on attitudes.

The Theory of Planned Behavior (TPB)(Ajzen, 1991), revised from the Theory of Reasoned Action (TRA), states the attitudes have a significant effect on behavioral intentions, and the intention to mediate the relationship between attitudes and actual behavior. Furthermore, (Kozinets, 1999) argues that virtual communities can affect the society and consumer behavior of the community member as well. The study conducted by (Y. Zhang, Wang, Wang, \& He, 2018) found that a sense of community among players in a gaming community is positively associated with buying behavior.

H6: It is assumed that SOVC can moderate the effect of attitude on purchase intention. 
International Journal of Business Management and Economic Review

Vol. 4, No. 04; 2021

ISSN: 2581-4664

According to (Sekaran \& Bougie, 2016) the analysis of SEM (Structural Equation Model) requires a sample of at least 5-10 times the number of indicator variables used. In this study, the total number of indicators was 26 . Thus the number of samples needed is $10 \times 26=260$ samples.

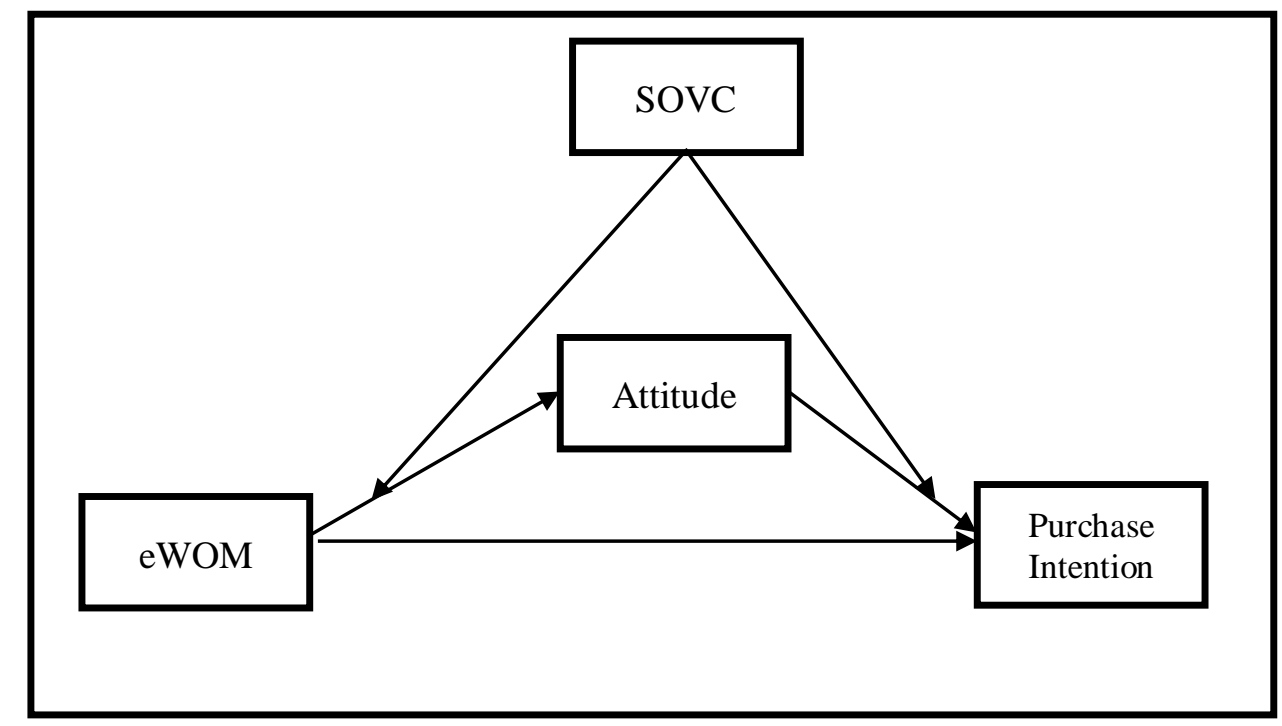

\section{RESEARCH METHOD}

Object of Research

The object of research is eWOM, SOVC, attitudes, and purchase intentions of the followers of the KPB Instagram account.

\section{Population and Sample}

The population in this study was all the official followers of the KPB Instagram account. Sample determined using a purposive sampling technique, which is sampling deliberately according to the required sample criteria.

\section{Data Collection Technique}

The data and information collection technique used in this study was a questionnaire. The prepared questionnaires were served based on each indicator of each variable. Then it was transformed into a google form and sent to respondents who were followers of the KPB Instagram account. Furthermore, the data collected through questionnaires were then analyzed using the SEM method with the help of the AMOS application (Hair, Babin, Anderson, \& Black, 2018).

\section{Variable Operation}

This study used eight (8) indicators based on (Goyette, Ricard, Bergeron, \& Marticotte, 2010) to measure the eWOM variable (independent variable). Attitude variable (mediation variable) applied six (6) indicators based on (Schiffman \& Kanuk, 2010), SOVC variable (moderation variable) used six (6) indicators based on (Koh \& Kim, 2003), and purchase intention (dependent variable) took six (6) indicators based on (Ajzen \& Fishbein, 2005). 


\section{International Journal of Business Management and Economic Review}

Vol. 4, No. 04; 2021

ISSN: 2581-4664

\section{RESULTS AND DISCUSSION}

\section{Characteristics of Respondents}

The results in Table 1 show that female respondents have the highest percentage of $53.5 \%$ or 139 respondents, and male respondents are $46.5 \%$. On the other hand, the age range of $24-29$ years old dominates at $44,6 \%$. Nonetheless, the result also shows the percentage from educational background, and the highest one is the college students in the amount of $56.5 \%$ with the highest percent of education level is Academy/Diploma Education (DIII/DIV) at $42.3 \%$. All respondents are aware of KPB's Instagram account and become followers in the community with a percentage of $100 \%$, more than some respondents or $61.9 \%$ knew about it from friends and stated that they had bought books based on information obtained from KPB as many as $84.6 \%$ of respondents.

\section{Table 1. Characteristics of Respondents}

\begin{tabular}{|c|c|c|}
\hline Characteristics of Respondents & Number of Respondents(n) & Percentage $(\%)$ \\
\hline \multicolumn{3}{|l|}{ Sex } \\
\hline Male & 121 & 46.5 \\
\hline Female & 139 & 53.5 \\
\hline \multicolumn{3}{|l|}{ Age } \\
\hline $18 \mathrm{~s} / \mathrm{d} 23$ Years old & 61 & 23.5 \\
\hline 24-29 Years old & 116 & 44.6 \\
\hline 30-35 Years old & 57 & 21.9 \\
\hline$>36$ Years old & 26 & 10.0 \\
\hline \multicolumn{3}{|l|}{ Employment Status } \\
\hline Civil Servant & 13 & 5 \\
\hline College Student & 147 & 56.5 \\
\hline Private Employee & 61 & 23.5 \\
\hline Entrepreneur & 32 & 12.3 \\
\hline Others & 7 & 2.7 \\
\hline \multicolumn{3}{|l|}{ Tertiary Education } \\
\hline High School & 22 & 8.5 \\
\hline Academy/Diploma & 110 & 42.3 \\
\hline Undergraduate (S-1) & 101 & 38.8 \\
\hline Postgraduate (S-2) & 24 & 9.2 \\
\hline Doctoral (S-3) & 3 & 1.2 \\
\hline \multicolumn{3}{|c|}{ Knowing about KPB (Komunitas Pecandu Buku) } \\
\hline Yes & 260 & 100 \\
\hline No & 0 & 0 \\
\hline \multicolumn{3}{|l|}{ Member of KPB } \\
\hline Yes & 260 & 100 \\
\hline No & 0 & 0 \\
\hline
\end{tabular}


International Journal of Business Management and Economic Review

Vol. 4, No. 04; 2021

ISSN: 2581-4664

\begin{tabular}{|l|c|c|}
\hline \hline \multicolumn{2}{|l|}{ Source of Information about KPB } \\
\hline Social Media & 99 & 38.1 \\
\hline Friend & 161 & 61.9 \\
\hline ConsideringThe Referencesof PKB to Buy Book(s) \\
\hline Ever & 220 & 84.6 \\
\hline Never & 40 & 15.4 \\
\hline
\end{tabular}

Validity and Reliability Test

CFA (Confirmatory Factor Analysis) Test

The CFA test aims to measure the conceptualized indicators correctly and consistently on forming the construct studied (valid). The construct CFA test in this study consisted of 4 variables. They are eWOM, attitude, SOVC, and purchase intention. An indicator is said to be valid if the loading factor value $>0.5$

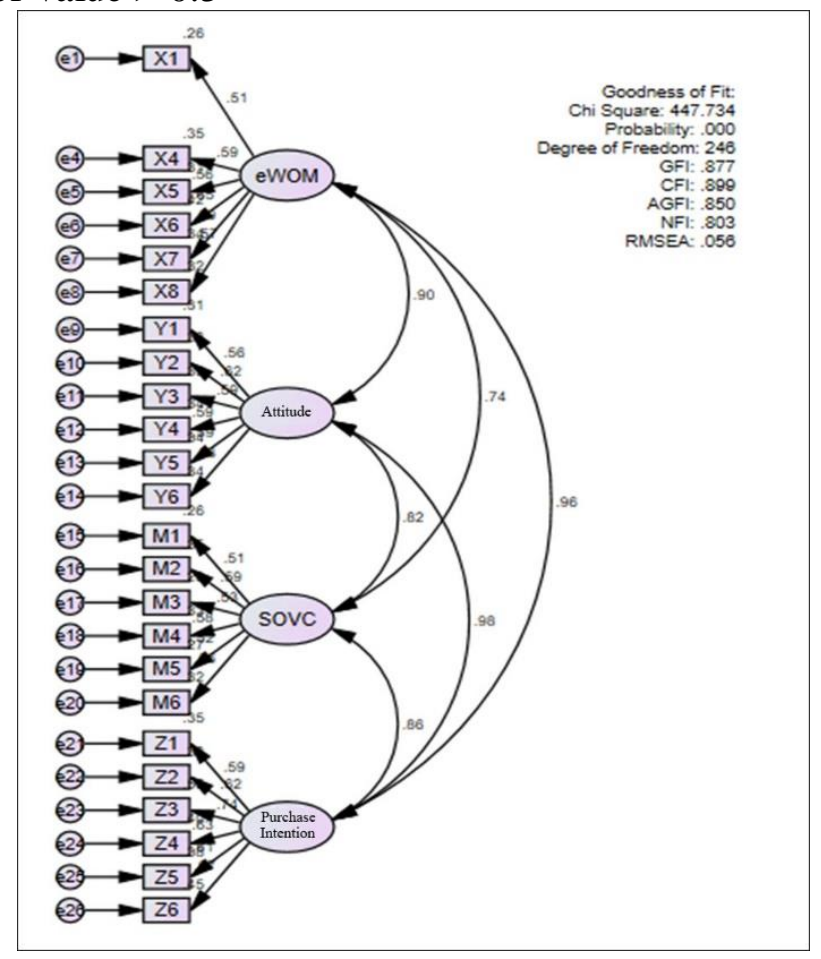

Figure 2. CFA Test 
International Journal of Business Management and Economic Review

Vol. 4, No. 04; 2021

ISSN: 2581-4664

From the results of the CFA test contained in Figure 2, all indicators are worth $>0.5$. Thus, all tested indicators are declared valid.

Reliability Test

Reliability testing using composite Construct Reliability (CR). The reliability test values for each variable are served based on their respective indicators in Table 2 below:

Table 2.Reliability Test

\begin{tabular}{|c|c|c|c|}
\hline Variable & Indicator & CR & Detail \\
\hline \multirow{6}{*}{ eWOM } & $\mathrm{X} 1$ & \multirow{6}{*}{0.773} & \multirow{6}{*}{ Reliable } \\
\hline & $\mathrm{X} 4$ & & \\
\hline & $\mathrm{X5}$ & & \\
\hline & X6 & & \\
\hline & $\mathrm{X} 7$ & & \\
\hline & $\mathrm{X} 8$ & & \\
\hline \multirow{6}{*}{ SOVC } & M1 & \multirow{6}{*}{0.723} & \multirow{6}{*}{ Reliable } \\
\hline & M2 & & \\
\hline & M3 & & \\
\hline & M4 & & \\
\hline & M5 & & \\
\hline & M6 & & \\
\hline \multirow{6}{*}{ Attitude } & Y1 & \multirow{6}{*}{0.768} & \multirow{6}{*}{ Reliable } \\
\hline & Y2 & & \\
\hline & $\mathrm{Y3}$ & & \\
\hline & $\mathrm{Y} 4$ & & \\
\hline & Y5 & & \\
\hline & Y6 & & \\
\hline \multirow{6}{*}{ Purchase Intention } & $\mathrm{Z1}$ & \multirow{6}{*}{0.811} & \multirow{6}{*}{ Reliable } \\
\hline & $\mathrm{Z} 2$ & & \\
\hline & $\mathrm{Z3}$ & & \\
\hline & $\mathrm{Z4}$ & & \\
\hline & $\mathrm{Z5}$ & & \\
\hline & Z6 & & \\
\hline
\end{tabular}

In Table 2 the CR value of each variable, eWOM, SOVC, Attitude, and Purchase Intention, has a value greater than the cut-off value $(<0.7)$, then all construct variables in this study are declared to have good reliability.

\section{Goodness of Fit}

The results of data processing for the fully SEM model analysis are shown in Figure 3 below: 


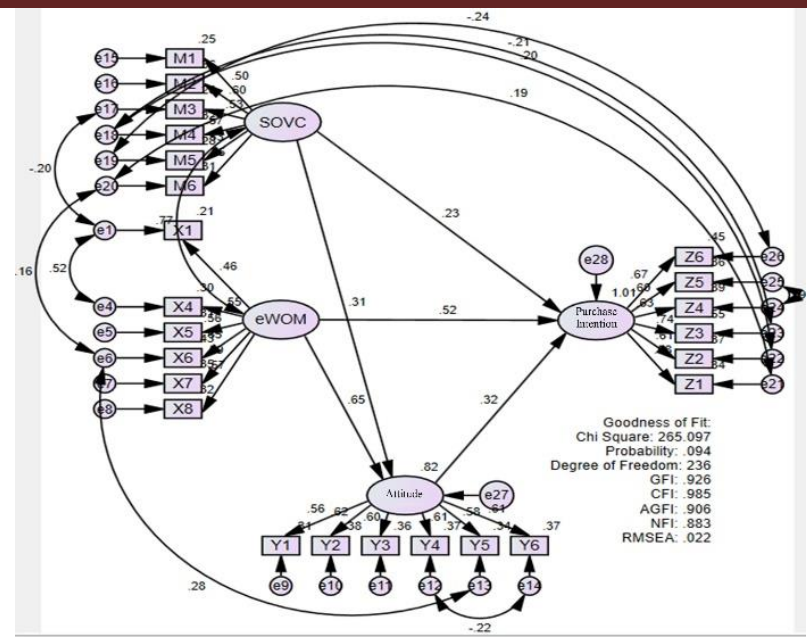

Figure 3. Structural Model Test

Based on the fulled structure measurement in Figure 3, the displayed results of the suitability test (GoF test) is in Table 3 below:

Table 3. Goodness of Fit

\begin{tabular}{|l|c|c|c|}
\hline \multicolumn{1}{|c|}{ Fit Model } & Value & Cut Of Value & Conclusion \\
\hline Chi-Square $(\mathrm{df}=236)$ & 265.097 & $\leq 308.870$ & Fit \\
\hline Probability & 0.094 & $\geq 0.05$ & Fit \\
\hline CMIN/DF & 1.123 & $\leq 2.00$ & Fit \\
\hline RMSEA & 0.022 & $\leq 0.08$ & Fit \\
\hline GFI & 0.926 & $\geq 0.90$ & Fit \\
\hline CFI & 0.985 & $\geq 0.90$ & Fit \\
\hline NFI & 0.883 & $\geq 0.90$ & Moderate Fit \\
\hline
\end{tabular}

From Table 3 above, the overall Full Model concluded is an acceptable Fit Model. It is because all the Goodness of Fit (GoF) assessed stands based on a minimum of 5 (five) criteria (Hair et al., 2018).

\section{Direct Effect Hypothesis Test Result (H1, H2, and H3)}

The results of the direct influence test can be seen in Table 4 below:

\section{Table 4. Direct Effect Test Result}

\begin{tabular}{|c|c|c|c|c|c|c|c|}
\hline \multicolumn{2}{|c|}{ Variabel } & Estimate & S.E. & C.R. & $\mathrm{P}$ & Label & $\beta$ \\
\hline Sikap & $<---\quad$ eWOM & .930 & .133 & 7.007 & $* * *$ & par_16 & .895 \\
\hline Niat_Bel & $<---$ eWOM & .806 & .266 & 3.030 & .002 & par_15 & .629 \\
\hline Niat_Bel & $<---\quad$ Sikap & .493 & .240 & 2.050 & .040 & par_17 & .400 \\
\hline$\ldots \ldots$ & $\ldots \ldots \quad \ldots \ldots$ & $\ldots \ldots$ & ..... & $\ldots \ldots$ & $\ldots$ & $\ldots \ldots$ & $\ldots \ldots$ \\
\hline
\end{tabular}




\section{International Journal of Business Management and Economic Review}

Vol. 4, No. 04; 2021

ISSN: 2581-4664

Table 4 shows that the P-value of the influence of the eWOM variable on attitudes is $<0.05$. The $\mathrm{P}$-value proves that the effect of eWOM on attitudes is significant. The magnitude of eWOM effect on attitudes is $(\beta)=0.895$ or $89.5 \%$, which indicates that the variable eWOM has a positive and significant effect on the attitudes. Also concluded from the explanation, hypothesis 1 is accepted where eWOM has a positive and significant effect on the attitude of followers of the KPB Instagram account. The results of this study are under the findings of (Fu et al., 2015) and (Yan et al., 2018), that increasing e-WOM follows the improvement of the attitude.

Furthermore, Table 4 also shows that the P-value of the influence of the eWOM variable on purchase intention is $0.002<0.05$ where this value proves that the effect of eWOM on purchase intention is significant. The magnitude of the effect of eWOM on purchase intention is $(\beta)=$ 0.629 or $62.9 \%$, which indicates that the eWOM variable has a positive and significant effect on the purchase intention of the followers of the KPB Instagram account. Concluded from the explanation, this study shows that eWOM has a positive and significant effect on purchase intention, which means hypothesis 3 is accepted. The results of this study are following the findings of (Doh \& Hwang, 2009) and (Wang \& Wang, 2010), that say the increase in eWOM ables to increase purchase intention.

Table 4 also displays that the P-value of the influence of the attitude variable on the intention is $0.040<0.05$, which proves that the effect of attitude on the purchase intention is significant. The magnitude of the influence of attitude on purchase intention is $(\beta)=0.400$ or $40 \%$, which indicates that the attitude variable has a positive and significant effect on the purchase intention of followers of the KPB Instagram account. The results of this study are following the findings of (Zahri \& Hafasnuddin, 2016) and (Han, 2017). It states that an increase in eWOM, once again, can also increase purchase intention.

Indirect Effect Hypothesis Test (H4)

The results of testing the indirect effect hypothesis can be seen in Table 5 below:

Table 5.Standardized of Indirect Effects

\begin{tabular}{|l|ccc|}
\hline & eWOM & Sikap & Niat Beli \\
\hline Sikap & .000 & .000 & .000 \\
Niat Beli & .358 & .000 & .000 \\
\hline
\end{tabular}

Table 5 shows an indirect effect of the eWOM variable on purchase intention through the attitude of 0.358. Furthermore, the significance of the indirect effect is shown in Figure 4 below.

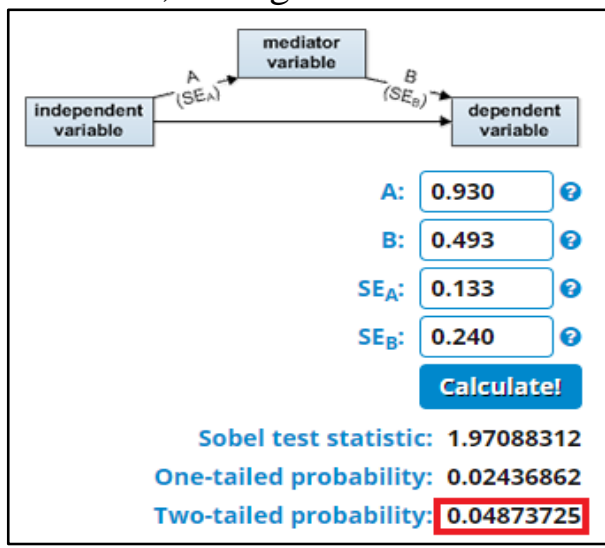

Figure 4. Sobel Test Calculator for H5 
International Journal of Business Management and Economic Review

Vol. 4, No. 04; 2021

ISSN: 2581-4664

Based on the results in Table 5 and Figure 4, the significance value of the indirect effect (Twotailed probability) or $(\mathrm{P})$ of the eWOM variable on purchase intention through attitude is 0.048 $<0.05$. These results indicate that the indirect effect is significant. Thus hypothesis 4 is accepted, which says that there is a positive and significant indirect effect of eWOM on purchase intention through the attitude of followers of the KPB Instagram account. These results are in line with research conducted by (J. Q. Zhang et al., 2010) and (Huang et al., 2012) that confirms that eWOM can affect purchase intention directly through attitude as a mediating variable.

Furthermore, to determine the type of attitude variable mediation, it can be seen in Table 6 below:

Table 6. Significance of Direct Effects and Indirect Effects

\begin{tabular}{|l|c|c|}
\hline \multicolumn{1}{|c|}{ Variabel } & $\begin{array}{c}\text { Pengaruh } \\
\text { Langsung }\end{array}$ & $\begin{array}{c}\text { Pengaruh Tidak } \\
\text { Langsung }\end{array}$ \\
\hline eWOM $\rightarrow$ Niat Beli & 0,002 (signifikan) & \\
\hline eWOM $\rightarrow$ Sikap & 0,000 (signifikan) & \\
\hline eWOM $\rightarrow$ Sikap $\rightarrow$ Niat Beli & & 0,048 (signifikan) \\
\hline
\end{tabular}

From Table 6, the significance of both direct and indirect effects all show significant results. The conclusion is that the attitude variable is a partial mediation. It means that eWOM does not directly affect purchase intention, but it is necessary to have a positive attitude from followers of the PKB Instagram account at the beginning. In other words, the higher the quality of eWOM received, the more positive attitudes will be. So, in the end, the increase in positive attitudes will be followed by the purchase intention enhancement of followers of the KPB Instagram account.

\section{Moderation Effect Test (H5 and H6)}

H5 : eWOM Effect Test toward Attitudes Moderated by SOVC

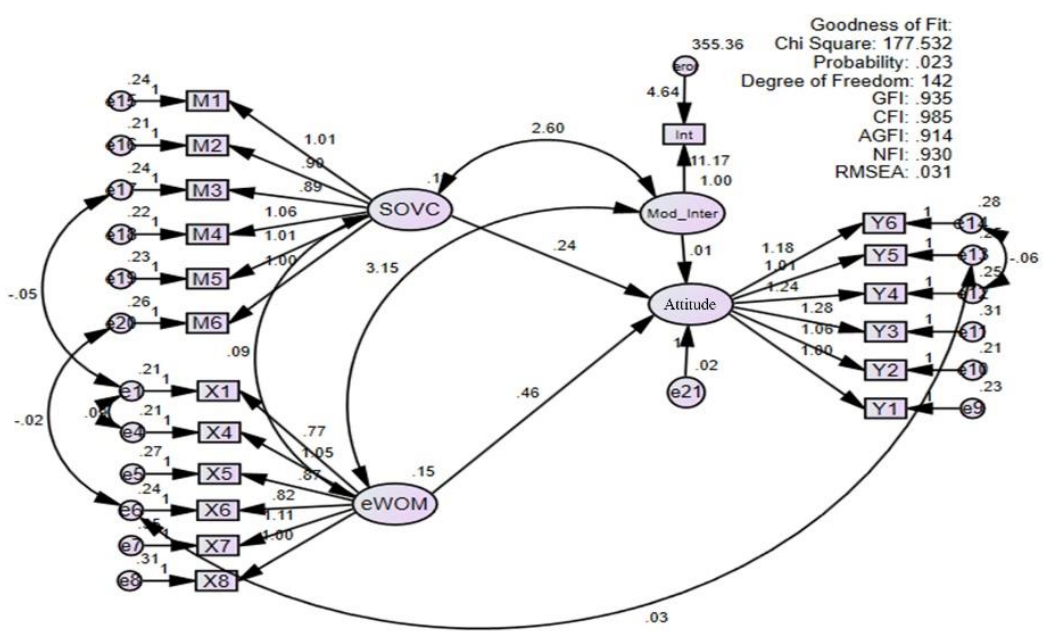

Figure5.Testing the SOVC Moderating Interaction Model on eWOM Effect toward Attitude 
International Journal of Business Management and Economic Review

Vol. 4, No. 04; 2021

ISSN: 2581-4664

The display in Figure 5 above shows that the GOF on the model is good. The estimation output results from the calculations based on Figure 5 are as follows:

Table 7.The Estimation of SOVC Moderation on The eWOM Effect toward Attitude

\begin{tabular}{|llrlllll|}
\hline & & Estimate & S.E. & C.R. & P & Label & $\beta$ \\
Sikap <--- & eWOM & .464 & .113 & 4.104 & $* * *$ & par_16 & .535 \\
Sikap <--- & SOVC & .237 & .122 & 1.944 & .052 & par_17 & .234 \\
Sikap <--- & Mod_Inter & .007 & .001 & $\mathbf{6 . 8 5 5}$ & $* * *$ & par_19 & $\mathbf{. 0 2 0}$ \\
\hline
\end{tabular}

From Table 7, the P-value of the influence of the interaction moderation variable on attitudes is $* * *$ (*** meaning less than 0.000 ) $<0.05$. This value proves that SOVC moderation on the effect of eWOM on attitudes is significant. The magnitude of the effect of moderating interaction on attitudes is 0.020 or $2 \%$, which indicates that the moderating variable SOVC can strengthen the effect of eWOM on attitudes positively and significantly by $2 \%$. The higher the SOVC moderation, the stronger the influence of eWOM on the attitude of followers of the KPB Instagram account can be. This explanation concluded that hypothesis 6 is accepted, which means SOVC moderation can strengthen the effect of eWOM on attitudes in a positive and significant way. The results of this study are in line with research conducted by (Herr et al., 1991) and (Huang et al., 2012) that say SOVC positively and significantly moderates the effect of eWOM on attitudes.

H6 : Attitude Effect Test toward Purchase Intention Moderated by SOVC

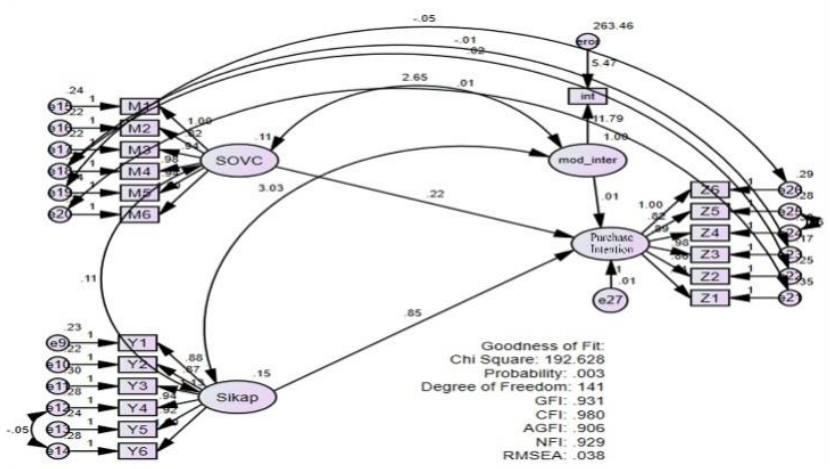

Figure 6. Testing the SOVC Moderating Interaction Model on Attitude Effect toward Purchase Intention

It can be seen from Figure 6 that the GOF on the model is good. The estimation output results from the calculations based on the picture above are as follows:

Table 8. The Estimation of SOVC Moderation on Attitude Effect toward Purchase Intention

\begin{tabular}{|c|c|c|c|c|c|c|c|}
\hline Niat_Beli & <-- Sikap & $\begin{array}{r}\text { Estimate } \\
.851\end{array}$ & $\begin{array}{l}\text { S.E. } \\
.171\end{array}$ & $\begin{array}{r}\text { C.R. } \\
4.963\end{array}$ & $\begin{array}{r}\mathrm{P} \\
* * *\end{array}$ & $\begin{array}{l}\text { Label } \\
\text { par_16 }\end{array}$ & $\begin{array}{c}\beta \\
.695\end{array}$ \\
\hline Niat_Beli & $<--\quad$ SOVC & .220 & .175 & 1.251 & .211 & par_17 & .155 \\
\hline Niat_Beli & $<---$ mod_inter & .009 & .001 & 7.594 & $* * *$ & par_19 & .019 \\
\hline
\end{tabular}




\section{International Journal of Business Management and Economic Review}

Vol. 4, No. 04; 2021

ISSN: 2581-4664

Thus, Table 8 shows that the P-value of the influence of the interaction moderation variable on purchase intention is $* * *$ (*** meaning less than 0.000$)<0.05$. This value proves that the SOVC moderation on the effect of attitude on purchase intention is significant. The magnitude of the moderating effect of interaction on purchase intention is $(\beta)=0.019$ or $1.9 \%$, which indicates that the SOVC moderating variable strengthens the influence of attitude on purchase intention positively and significantly. Based on this explanation, hypothesis 7 is accepted, which means that in this research SOVC moderation strengthens the effect of attitude on purchase intention in a positive and significant way on KPB's Instagram account followers that supported by the findings by (Y. Zhang et al., 2018), and (Canossa, Azadvar, Harteveld, Drachen, \& Deterding, 2019)who found that SOVC had a positive and significant role as a moderator between the effects of attitude on purchase intention.

From the results of two moderating hypothesis testing, as shown in Table 7 and Table 8 , it is known that the significance coefficient of each moderating variable on the dependent variable is not significant. Vice versa, the significance coefficient between the moderating variable*interaction on the dependent variable turns out significant. To sum up, SOVC is a pure moderating variable (pure moderator), thus makes the SOVC variable is a pure moderator that interacts with the independent variable without being a predictor variable.

\section{CONCLUSION}

Academically, this study proves that the model consisting of the mediating effect of attitude on the relationship of eWOM to purchase intention and the moderating effect of SOVC on the relationship of eWOM on attitudes and the relationship of attitude on the purchase intention of followers of the KPB Instagram account can be used to increase purchase intention. Practically, this model can be implemented in organizations, especially the subject of this research, namely the KBP Instagram account. The eWOM variable is the variable in the model that is proven to be the most dominant in influencing the purchase intention of KPB's Instagram account followers. Therefore, these findings reveal that in the future, KPB Instagram account managers must pay attention to and be able to maintain interactions between community members as part of the contribution to continue to increase positive attitudes on followers interaction through reviews or comments on their Instagram accounts. The formation of a positive attitude between followers will automatically increase interest in buying followers of the KPB Instagram account.

This research was conducted limited to only one online community on one of Instagram accounts named KPB. Therefore, the following research should increase the scope of research with more diverse research subjects such as Facebook, Pinterest, and other social media. Regarding the variables used in this study that only include eWOM, attitude, and SOVC variables,further research can add the other variables that affect purchase intention, such as brand image and customer experience. In addition, the indicators also can probably be adjusted from this study with many kinds of relevant indicators for upgraded future research.

\section{REFERENCES}

Ajzen, I. (1991). The theory of planned behavior. Organizational Behavior and Human Decision Processes, 50(2), 179-211. https://doi.org/https://doi.org/10.1016/0749-5978(91)90020-T 


\section{International Journal of Business Management and Economic Review}

Vol. 4, No. 04; 2021

ISSN: 2581-4664

Ajzen, I., \& Fishbein, M. (1980). Understanding Attitudes and Predicting Social Behavior. America: Prentice-Hall.

Ajzen, I., \& Fishbein, M. (2005). The Influence of Attitudes on Behavior (D. Albarracín, B. T. Johnson, \& M. P. Zanna, Eds.). Mahwah, NJ: Lawrence Erlbaum Associates.

Bansal, H. S., \& Voyer, P. A. (2000). Word-of-Mouth Processes within a Services Purchase Decision Context. Journal of Service Research, 3(2), 166-177. https://doi.org/https://doi.org/10.1177/109467050032005

Blanchard, A. L., \& Markus, M. L. (2004). The Experienced "Sense" of a Virtual Community: Characteristics and Processes. ACM SIGMIS Database, 35(1), 64-79. https://doi.org/10.1145/968464.968470

Bone, P. F. (1995). Word-of-mouth effects on short-term and long-term product judgments. Journal of Business Research, 32(3), 213-223. https://doi.org/https://doi.org/10.1016/01482963(94)00047-I

Brown, J., Broderick, A. J., \& Lee, N. (2007). Word of Mouth Communication Within Online Communities: Conceptualizing the Online Social Network. Journal of Interactive Marketing, 21(3), 2-20. https://doi.org/10.1002/dir.20082

Buda, R. (2003). The interactive effect of message framing, presentation order, and source credibility on recruitment practices. International Journal of Management, 20(2), 156.

Canossa, A., Azadvar, A., Harteveld, C., Drachen, A., \& Deterding, S. (2019). Influencers in Multiplayer Online Shooters: Evidence of Social Contagion in Playtime and Social Play. Proceedings of the 2019 CHI Conference on Human Factors in Computing Systems, 1-12. https://doi.org/https://doi.org/10.1145/3290605.3300489

Cheung, M. Y., Luo, C., Sia, C. L., \& Chen, H. (2009). Credibility of electronic word-of-mouth: Informational and normative determinants of on-line consumer recommendations. International Journal of Electronic Commerce, 13(4), 9-38. https://doi.org/https://doi.org/10.2753/JEC10864415130402

Doh, S.-J., \& Hwang, J.-S. (2009). How consumers evaluate eWOM (electronic word-of-mouth) messages. Cyberpsychology \& Behavior: The Impact of the Internet, Multimedia and Virtual Reality on Behavior and Society, 12(2), 193-197. https://doi.org/10.1089/cpb.2008.0109

Feldman, J. M., \& Lynch, J. G. (1988). Self-Generated Validity and Other Effects of Measurement on Belief, Attitude, Intention, and Behavior. Journal of Applied Psychology, 73(3), 421-435. https://doi.org/10.1037/0021-9010.73.3.421

$\mathrm{Fu}$, J.-R., Ju, P.-H., \& Hsu, C.-W. (2015). Understanding why consumers engage in electronic word-of-mouth communication: Perspectives from theory of planned behavior and justice theory. Electronic Commerce Research and Applications, 14(6), 616-630. https://doi.org/https://doi.org/10.1016/j.elerap.2015.09.003

Goyette, I., Ricard, L., Bergeron, J., \& Marticotte, F. (2010). Scale: word-of-mouth measurement scale for e-services context. Canadian Journal of Administrative Sciences, 27(1), 5-23. https://doi.org/10.1002/cjas.129

Hair, J. F., Babin, B. J., Anderson, R. E., \& Black, W. C. (2018). Multivariate Data Analysis (8th Ed.). London: Pearson.

Han, W. (2017). Consumer Attitudes and Purchase Intentions of Cruises in China (The University of Nevada, Las Vegas). https://doi.org/http://dx.doi.org/10.34917/11156726 


\section{International Journal of Business Management and Economic Review}

Vol. 4, No. 04; 2021

ISSN: 2581-4664

Herr, P. M., Kardes, F. R., \& Kim, J. (1991). Effects of Word-of-Mouth and Product-Attribute Information on Persuasion: An Accessibility-Diagnosticity Perspective. Journal of Consumer Research, 17(4), 454-462. Retrieved from https://www.jstor.org/stable/2626839

Huang, J.-H., Hsiao, T.-T., \& Chen, Y.-F. (2012). The Effects of Electronic Word of Mouth on Product Judgment and Choice: The Moderating Role of the Sense of Virtual Community. Journal of Applied Social Psychology, 42(9), 2326-2347. https://doi.org/https://doi.org/10.1111/j.15591816.2012.00943.x

Jalilvand, M. R., \& Samiei, N. (2012). The effect of electronic word of mouth on brand image and purchase intention: An empirical study in the automobile industry in Iran. Marketing Intelligence \& Planning, 30(4), 460-476. https://doi.org/10.1108/02634501211231946

Jasman, G. K., \& Lubis, P. H. (2017). Tingkat Niat Pembelian Online Shop Di Kalangan Mahasiswa Universitas Syiah Kuala. Jurnal Ilmiah Mahasiswa Ekonomi Manajemen, 2(1), 98113. https://doi.org/https://doi.org/10.24815/jimen.v2i1.3564

Kaplan, A. M., \& Haenlein, M. (2010). Users of the world, unite! The challenges and opportunities of Social Media. Business Horizons, 53(1), 59-68. https://doi.org/https://doi.org/10.1016/j.bushor.2009.09.003

Kim, M., \& Hunter, J. E. (1993). Relationships among attitudes, behavioral intentions, and behavior: A meta-analysis of past research: II. Communication Research, 20(3), 331-364. https://doi.org/https://doi.org/10.1177/009365093020003001

Koh, J., \& Kim, Y.-G. (2003). Sense of virtual community: A conceptual framework and empirical validation. International Journal of Electronic Commerce, 8(2), 1-9.

Kozinets, R. V. (1999). E-tribalized marketing?: the strategic implications of virtual communities of consumption. European Management Journal, 17(3), 252-264. https://doi.org/https://doi.org/10.1016/S0263-2373(99)00004-3

Park, D.-H., \& Kim, S. (2008). The effects of consumer knowledge on message processing of electronic word-of-mouth via online consumer reviews. Electronic Commerce Research and Applications, 7(4), 399-410. https://doi.org/https://doi.org/10.1016/j.elerap.2007.12.001

Rahman, M., Haque, M., Elahi, F., \& Miah, W. (2015). Impact of Organizational Justice on Employee Job Satisfaction: An Empirical Investigation. American Journal of Business and Management, 4(4), 162-171. https://doi.org/https://doi.org/10.11634/216796061706714

Roberts, L. D., Smith, L., \& Pollock, C. (2006). Psychological sense of community in virtual communities. In Encyclopedia of virtual communities and technologies (pp. 390-396). USA: Idea Group IncEditors: S. Dasgupta.

Schiffman, L., \& Kanuk, L. (2010). Consumer Behavior (11th ed.). London: Pearson.

Sekaran, U., \& Bougie, R. (2016). Research Methods For Business: A Skill Building Approach (7th Ed.). New Jersey: John Wiley \& Sons.

Solomon, M. R., \& Rabolt, N. J. (2004). Consumer Behavior: In Fashion. New Jersey: Prentice Hall.

Sotiriadis, M. D., \& Zyl, C. van. (2013). Electronic word-of-mouth and online reviews in tourism services: the use of twitter by tourists. Electronic Commerce Research, 13, 103-124. https://doi.org/10.1007/s10660-013-9108-1

Wang, C.-C., \& Wang, Y.-T. (2010). Persuasion Effect of e-WOM: The Impact of Involvement and Ambiguity Tolerance. Journal of Global Academy of Marketing Science, 20(4), 281-293. https://doi.org/https://doi.org/10.1080/12297119.2010.9707433 
International Journal of Business Management and Economic Review

Vol. 4, No. 04; 2021

ISSN: 2581-4664

Yan, X., Shah, A., Zhai, L., \& Khan, S. (2018). Impact of mobile electronic word of mouth (EWOM) on consumers purchase intentions in the fast-causal restaurant industry in Indonesia. Proceedings of the 51st Hawaii International Conference on System Sciences, 3801-3810. https://doi.org/10.24251/HICSS.2018.479

Zahri, Y., \& Hafasnuddin. (2016). The influence of religiosity on interest in buying Islamic bank products/services with attitude (study on conventional bank customers in Banda Aceh City). Jurnal Ilmiah Mahasiswa Ekonomi Manajemen, 1(1), 75-91. https://doi.org/https://doi.org/10.24815/jimen.v1i1.58

Zhang, J. Q., Craciun, G., \& Shin, D. (2010). When does electronic word-of-mouth matter? A study of consumer product reviews. Journal of Business Research, 63(12), 1336-1341. https://doi.org/10.1016/j.jbusres.2009.12.011

Zhang, Y., Wang, J., Wang, Y., \& He, Y. (2018). Research on effect of virtual community internet interaction to online purchasing behavior. Conference: 2018 4th International Conference on Information Management (ICIM), 66-70. https://doi.org/10.1109/INFOMAN.2018.8392811 